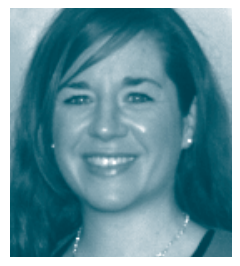

Rachel Reitan, mastergrad sykepleie, universitetslektor, Universitetet i Nordland. Oversatt av Knut Dybwik.

\title{
Mobile akutteam
} redder liv

\author{
Både Sverige og Danmark har innført velfungerende akutteam \\ på nasjonal basis. Hvorfor har vi ikke gjort det samme i Norge?
}

K onseptet «Rapid respons» har som mål å oppdage tidlige signaler på forverring i pasientens tilstand, slik at tiltak for å redusere komplikasjoner og forhindre død kan settes i verk tidlig. Mobilt akutteam (MAT) er innført på verdensbasis på bakgrunn av forskning som støtter sammenhengen mellom MAT og reduksjon i forekomsten av både hjertestans og dødelighet $(1,2)$, samt økt tilfredshet hos personalet (3). Til tross for overbevisende forskningsfunn ved bruk av tidlige varslingssystemer, har Norge fortsatt ikke fulgt sine europeiske og skandinaviske naboers eksempel med å innføre MAT på nasjonal basis. Hensikten med denne artikkelen er å undersøke Norges motvilje mot å innføre MAT-konseptet og presentere en løsning for hvordan man kan innføre MAT-systemet i norske sykehus på en vellykket måte.

\section{Hva er MAT?}

Mobilt akutteam (MAT) er et team av akuttmedisinske eksperter, vanligvis intensivsykepleiere og en anestesilege, som kalles ut til risikopasienter på sengeposter. De skal vurdere, behandle og forhindre ytterligere forverring av pasientens tilstand. MAT fører til færre uheldige behandlingsresultater, redusert mortalitet, og det reduserer antall døgnopphold i sykehus $(2,4)$. Med MAT-systemet kan sykepleiere som er bekymret for pasientens tilstand lettere kontakte akuttmedisinske eksperter. Gjennom rask vurdering, øyeblikkelige tiltak, kommunikasjon og opplæring, kan MAT fremme en kultur hvor støtte og samarbeid mellom akuttmedisinsk personale og medisinske- og kirurgiske sykepleiere står sentalt (3). Sykepleierne blir også flinkere til å oppdage forverring i pasientens tilstand (3). MAT-konseptet er godkjent og anbefalt av medisinske organisasjoner over hele verden (5).

MAT tilkalles av sykepleiere på vanlig medisinske og kirurgiske sengeposter på bakgrunn av de vanligste fysiologiske varselsignalene (se tabell 1) eller hvis en sykepleier får «en dårlige følelse.» Når MAT varsles forsøker de å behandle pasienten på sengeposten for å unngå overflytting til intensivavdelingen. Men for eksempel ved behov for intubering eller intensivmonitering, kan pasienten likevel overføres.
TABELL 1: Kriterier for MAT-utrykkning

\begin{tabular}{|l|l|}
\hline Organsystem & Signaler \\
\hline Respiratoriske & $\begin{array}{l}\mathrm{RF}<8 \text { or }>30 \\
\mathrm{SpO} 2<90 \% \text { med } 02 \text { terapi }\end{array}$ \\
\hline Sirkulatoriske & $\begin{array}{l}\mathrm{MAP}<60 \text { or }>130 \mathrm{~mm} \\
\mathrm{Hg} \mathrm{HF}<45 \text { or }>125 \mathrm{SPM} \\
\text { Brystsmerter } \\
\text { Diurese }<50 \mathrm{ml} \text { over } 4 \text { timer }\end{array}$ \\
\hline Neurologiske & $\begin{array}{l}\text { Nedsatt bevissthet } \\
\text { Forandring i mentalstatus }\end{array}$ \\
\hline Andre & En pleier er bekymret for en pasient \\
\hline
\end{tabular}

Notat. $R F=$ respirasjonsfrekvens, $\mathrm{SpO} 2=$ oxygen saturasjon, $M A P=$ middelarterietrykk, $H F=$ hjertefrekvens, $S P M=\operatorname{slag}$ per minutt (6)

\section{Problemer og utfordringer}

Svikt i å gi rask og kompetent pleie til en pasient på en sengepost som er blitt akutt syk, kan føre til uventede komplikasjoner og død (7). Ifølge en rapport fra Institute of Medicine ble det estimert at omtrent 100000 dødsfall i amerikanske sykehus skyldtes slik svikt (8). I 2007 undersøkte Akershus universitetssykehus over 1000 journaler og fant at nesten 20 prosent av pasientene ble påført en uventet hendelse (9). Norsk Pasientskadeerstatning (NPE) brukte over 750 millioner kroner på pasientskader i 2009 (10). Uventede hendelser og dødsfall i sykehus er et stort problem for pasientsikkerhet over hele verden. De fleste sykehus har «stansteam» når det oppstår akutte situasjoner, som hjerte- eller respirasjonsstans. Men flere og flere klinikere og forskere mener at dette teamet ofte kommer altfor seint og at deres kompetanse burde ha blitt brukt før en akutt hjerte- eller respirasjonsstans oppstår (5). Hjertestans er vanligvis den siste hendelsen i en rekke fysiologiske signaler som varsler at pasientens tilstand forverres (1). Før hjertestans har opp til 80 prosent av pasientene tydelige 


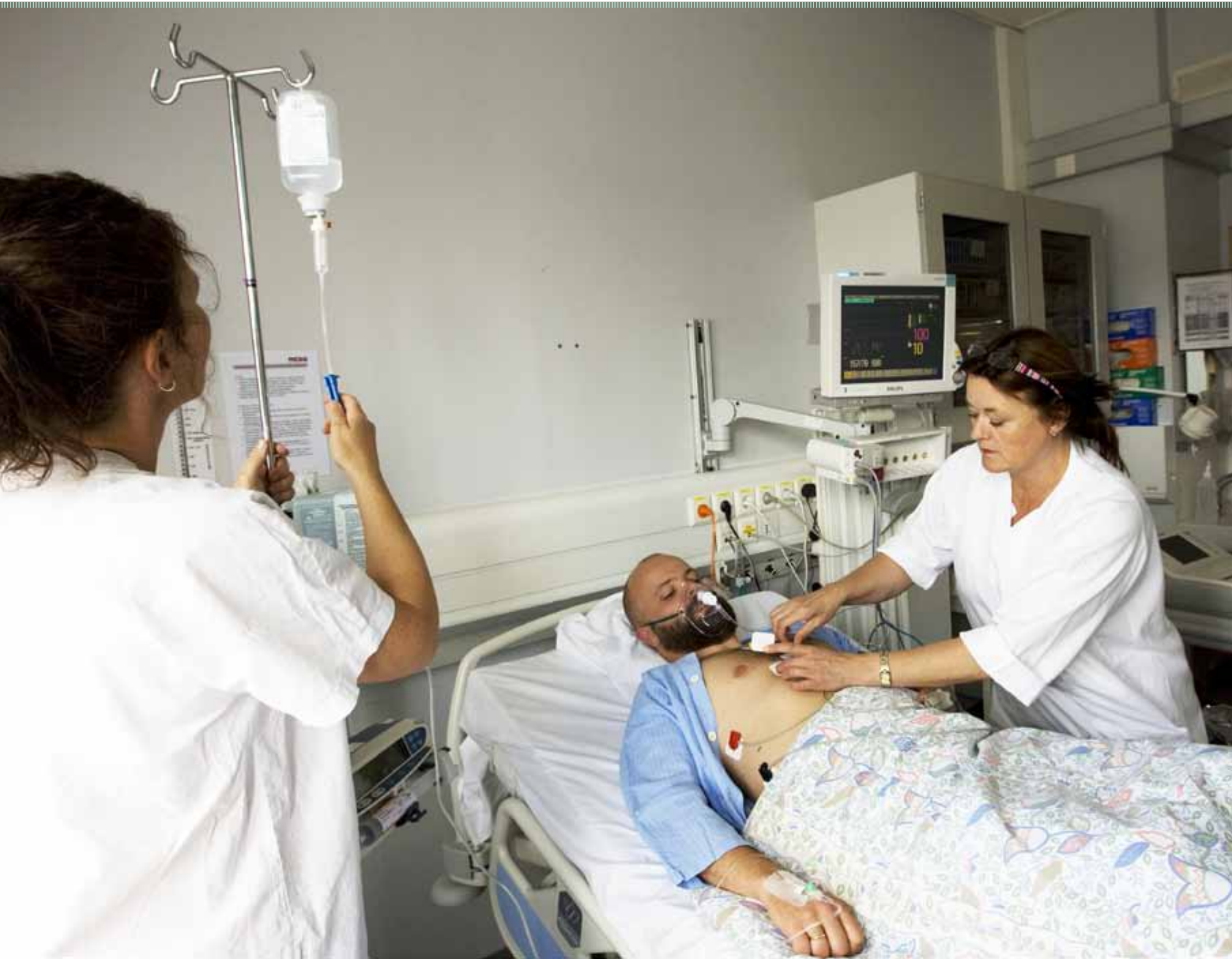

ФYEBLIKKELIG HJELP: Mobilt akutteam er et team med akuttmedisinske eksperter og består vanligvis av intensivsykepleiere og en anestesilege. Foto: Gorm Kallestad/Scanpix

fysiologisk tegn på forverring, og vitale kroppsfunksjoner er unormale åtte timer før hjertestans inntreffer hos halvparten av de som får hjertestans på sykehus $(11,12)$. På bakgrunn av dette kommer «stansteam» vanligvis altfor seint (5).

\section{Mangel på nivå-1 evidens}

De aller fleste studiene som viser en sammenheng mellom MAT og et synkende antall hjertestans eller dødsfall i sykehus, er prospektive før- og etterstudier eller ikke-randomiserte kontrollstudier. Disse representer nivå 2-forskning (5). Noen argumenterer med at man trenger mer forskning på nivå 1 for å rettferdiggjøre utviklingen av tidlige varslingssystemer. Bellemo et al. (7) hevder at dobbeltblindede randomiserte studier (nivå 1) av MAT er umulig å utføre. Aaneman og Karr (5) diskuterer de etiske konsekvensene av å gjennomføre randomiserte studier som potensielt ville forhindre behandling av akutt syke pasienter. Andre antyder til og med at en forsinkelse i innføringen av MAT i påvente av nivå 1-forskning er uetisk (13). I en systematisk litteraturgjennomgang utført av en av pionerene innenfor forskning på MAT-systemet, var konklusjonen at det finnes ingen funn som peker mot bruken av MAT og heller ingen bevis på at pasientskade har oppstått ved bruk av MAT (14).

\section{MERIT-studiet}

I 2005 utførte et team av forskere fra MERIT (Medical Emergency Response Improvement Team) det første randomiserte kontrollstudiet for å undersøke sammenhengen mellom MAT og reduksjonen i uplanlagte overføringer til intensivavdelinger, hjertestans og uventede dødsfall (15). Etter seks måneder konkluderte forskerne med at MAT-systemet økte antall akutteam som ble utkalt. Men dette hadde ingen signifikant effekt på resultatvariablene for overføringer til intensivavdelingene, hjertestans eller uventede dødsfall. Til tross for dette så man en reduksjon i antall hjertestans i begge gruppene (15).

Kunnskapssenteret i Norge bruker MERIT-studiet som hovedkilde for å stille spørsmål ved og til og med avvise bruken av MAT i norske sykehus (16). Dette til tross for at mange har stilt spørsmål om studiemetodene og resultatene $(5,7,17)$. I en 
artikkel fra 2008 skrev Rinaldo Bellemo, en av hovedforfatterne bak MERIT-studiet, at «dobbeltblindede randomiserte studier av MAT er umulig (s. 1).» Institute for Healthcare Improvement (IHI) publiserte en erklæring der de hevdet at til tross for et sterkt studiedesign kunne begrensninger og svakheter i studiet skyldes ufullstendig og inkonsekvent innføring av MAT i studiesykehus og delvis innføring av MAT i kontrollsykehus (det var vanskelig å finne sykehus i Australia som ikke allerede hadde innført MAT eller var i ferd med å gjøre det). Studiet var ikke sterkt nok til å oppdage en 30 prosent reduksjon i resultatvariablene (17). I en artikkel fra 2006 drøftet Aaneman og Karr (5) den «utilstrekkelige statistiske svakheten (s. 76)» i MERIT-studien, og mangel på medgjørlighet i studiesykehus fordi det var investert for lite tid

\section{MAT-systemet}

Både Sverige og Danmark har etablert velfungerende MATsystemer. Karolinska Universitetssjukhuset i Stockholm har sett en reduksjon i hjertestans fra 1,12 per 1000 innleggelser til 0,83 per 1000 innleggelser $(\mathrm{p}=0,035)$ og mortaliteten har blitt redusert med 12 prosent $(p=0,002)$ etter MAT ble etablert (1).

Innføring av MAT i norske sykehus fører til en lang rekke utfordringer knyttet til forandring i tradisjonelle tenkemåter og praksis i sykehus. Å utvikle et velfungerende team av intensivmedisinsk personell som rykker ut bedside til dårlige pasienter krever ressurser for å lykkes $(2,18)$.

\section{Struktur}

Med utgangspunkt i praksis fra andre skandinaviske land, og litteratur, bør MAT i Norge bestå av en anestesilege, en intensivsykepleier og pasientens primære sykepleier og lege på sengeposten. I samarbeid med sykepleier og lege på sengeposten har intensivsykepleier og anestesilege i oppgave å konsultere, undervise og legge til rette når de blir utkalt til en dårlig pasient. Deres ekspertise på behandling av kritisk syke, verdifull informasjon om pasienten og lagarbeid med sengepostpersonalet, styrer vurdering, identifisering og behandling av en potensielt kritisk tilstand. I tillegg skal de forhindre ytterligere forverring i pasientens tilstand, overføring til intensivavdelingen samt hjertestans eller død.

\section{Opplæring}

En avgjørende faktor for vellykket innføring av MAT er opplæring av medlemmene i det mobile akutteamet samt av leger og sykepleiere på sengeposten. Uten tilstrekkelig opplæring kan det hende at personalet ikke varsler når det er behov for det. Grunner til dette kan være at man overser betydningen av tidlig intervensjon, manglende evne til å gjenkjenne fysiologiske varselsignaler, frykt for å få skylden for pasientens forverrede tilstand og vanskeligheter med å bryte med den tradisjonelle handlemåten med å ringe pasientens primære lege (7). Tilstrekkelig opplæring vil dempe skepsisen som noen i personalet kan føle.

Opplæring av medisinsk personale fokuserer primært på å få fram fordelene med og fjerne myter knyttet til MAT. Medisinsk personale kan være nølende overfor et slikt system fordi sykepleiere får direkte tilgang til akutteamet. Leger kan også

\section{Medisinsk personale kan veere nølende overfor et slikt system fordi sykepleiere fär direkte tilgang til akutteamet.}

være nølende til å innføre et system som baserer seg på sykepleiernes selvstendige dømmekraft og gir dem mer makt i pasientomsorgen (7).

I utgangspunktet bør ikke medisinske og kirurgiske sykepleiere på sengepostene bli skremt fra eller redde for å kontakte MAT av frykt for at teamet vil ta over omsorgen. De kommer for å gi raske anbefalinger slik at pasienten slipper å bli overført til intensivavdeling.

\section{Konklusjon}

Innføring av MAT krever minimale økonomiske ressurser $(13,19)$. Den potensielle reduksjonen i hjertestans, dødelighet, liggedøgn på sykehus og økt jobbtilfredshet hos personalet kan gi reduserte kostnader.

Det overordnede målet med å innføre MAT er å redusere hjertestans i sykehus med 30 prosent, redusere dødelighet i sykehus med 20 prosent og øke sykepleiertrivselen. Dette kan måles gjennom pasientresultater og medarbeidertilfredshet.

Dokumentasjon av alle utrykningene er viktig for å evaluere og kontinuerlig forbedre MAT-systemet. Evaluering av denne dokumentasjonen vil avdekke behov for forbedringer og styre eventuelle endringer i den opprinnelige innføringsplanen for MAT. Evaluering bidrar også til å bedre utrykningssystemet til MAT i tillegg til responstid, intervensjonsmetoder, kommunikasjonsmetoder og andre viktige aspekter ved teamet. IIII
LITTERATUR

. Bell M, Granath F, Jaderling G, Konrad D, Ekbom A, Martling C. Reducing inhospital cardiac arrests and hospital mortality by introducing a medical
emergency team. Intensive Care Medicine 2010; 36: 100-106.

2. Bellemo R, Buckmater J, Doolan L, Goldsmith D, Gutterridge G, Hart Goldsmich D, Gutterridge G, Hart G. A prospective before-and-after Medical Journal of Australia 2003; 179: Medical Jo
283-287.

3. Dodd D, Rasmussen D, Thomas K, Force M, Whilden S. Rapid response team: Challenges, solutions, benefits. Critical Care Nurse 2007; 27(1): 20-27. . Devita M, Hillman K, Bellemo R. Medical Emergency Teams: Implementation and Outcome Measures. New
York, NY: Springer, 2006

5. Aaneman, A, Parr M. The ERC Guidelines for Resuscitation 2005 and the medical emergency team. Scandinavian Journal of Trauma, Resuscitation, and Emergency Medicine 2006; 14 : 74-77.

6. Institute for Healthcare Improvement (2006). Institute for Healthcare (2006). Instits for Healthcare Improvement: Establish a Rapid Response Team. Retrieved October 5 , 2009, from IH. http://www.ihi.org/ (II/Topics/CriticalCare/IntensiveCare/Changes/EstablishaRapidRe sponseTeam.htm

Bellemo R, Calzavacca P, Goldsmith D, Licari E, Tee A. Bench-to-bedside review: The MET sydrome - the chalenges of researching and adopting medical emergency teams. Critical
Care 2008; 12: 205-211.

8. Corrigan J, Donaldson M, Kohn L. To Err is Human: Building a Safer Health System. Washington, D.C.: Institute of Medicine, 2000

9. Svaar H. Journal Analysis to Uncover Patient Injuries. Patient Safety Conference. Oslo. Norway: Akershus University Hospital, 2007.

10. The Norwegian System of Compensation sation to Patients. (2010, February 2). . of Compensation to Patients: http:// npe.no

11. Franklin C, Mathew J. Developing strategies to prevent in hospital cardiac arrest: analyzing responses of physicians and nurses in the hours before the event. Critical Care Medicine
1994; 22 (2): 244-247.

12. Nurmi J. Observations and warning signs prior to cardiac arrest. Acta An Scand 2005; 49: 702-706.

13. Kerridge R, Saul W. The medical emergency team, evidence-beased medicine and ethics Medical Journal of Australia 2003: 179(6): 313-315.

14 . Bellemo R. Medical Emergency Teams: Evidence For and Against. 2009 Rapid Response Systems Conference. Victo.

MERIT study investigators. Introduction of the medical emergency team (MET) system: a cluster-randomiz controlled trial. Lancet 2005; 365 . 2091-2097.

16. Gilbert M. Patient Safety in Practice. The Norwegian Knowledge Center for Health Services. Tromsoe, Norway:
University Hospital of Northern Norway, 2006.

17. 100,000 Lives Campaign. The «MERIT» Trial of Medical Emergency Teams in Australia: An Analysis of Findings and Implications for the 100,000 Lives Campaign. Institute for Healthcare Improvement. Cambridge, MA:InstiImprovement. Cambridge, MA: Ins tute for

18. Bedker D, Corderella J, Hatler C Johnson R, King D, Mast D, et al. Implementing a rapid resonse team to decrase emergencies outside the ICU: One hospitalis experience. MedSurg One hospitalis experience. Medsu
Nursing 2009; 18(2): 84-93.

19. Wursing 2009; 18(2): 84-93. Implementing Rapid Response Teams. Dallas, TX: John Hopkins Bloomberg School of Publc Health, 2006. 